\title{
Insulin-Like Growth Factor System and Sporadic Malignant Melanoma
}

\section{Ettore Capoluongo}

From the Laboratory of Clinical Molecular Diagnostic, Institute of Biochemistry, and Clinical Biochemistry, Catholic University, Rome, Italy

Insulin and insulin-like growth factors (IGFs) are important regulators of energy metabolism and growth. Several findings have outlined an important role played by this family of molecules in both tumor maintenance and development. Despite the established contribution of the IGF system in carcinogenesis, little and contrasting data have been reported concerning the intertwined relationships between melanoma and this family of molecules. The present minireview aims to summarize the main topics and evidence concerning this malignant skin cancer, with a focus on the following: i) melanoma and cell proliferation effects induced by the IGF system, ii) in vitro and in vivo experimental data, and iii) targeting studies. Because of consistent findings regarding the role of the IGF-1 receptor in the modulation of IGF-1 activity, possible therapeutic strategies combining the use of antisense oligonucleotides against IGF-1 receptor mRNA could be applied in the future. (Am J Pathol 2011, 178:26-31; DOI: 10.1016/j.ajpath.2010.11.004)

Melanoma is a malignant tumor originating from melanocytes, the melanin-producing cells. ${ }^{1,2}$ During fetal development, melanocytes migrate to different body areas, such as the skin, uvea, leptomeninges, and mucous membranes (eg, upper esophagus, vulva, and anus). ${ }^{2}$ Although melanoma may arise in all these sites, cutaneous melanoma is by far the most frequent type of melanoma, representing approximately $5 \%$ to $7 \%$ of all skin malignancies and the most lethal skin cancer (approximately $75 \%$ of all deaths from skin tumors). ${ }^{2,3}$ The following melanoma risk factors have been extensively described: i) sun exposure, ii) presence of dysplastic nevi, iii) age, iv) ethnicity, v) personal or family history of melanoma, vi) phototype, vii) presence of xeroderma pigmentosum, viii) Li-Fraumeni syndrome, ix) hereditary retinoblastoma history, and $\mathrm{x}$ ) immunosuppressive conditions. ${ }^{4}$ In addition to environ- mental and individual risk factors, the genetic pedigree may also represent a further risk factor for melanoma development; indeed, multiple differences between melanoma cell genomes and those of normal melanocytes were identified in genomewide analysis studies. In particular, point mutations, deletions, gene amplifications and translocations, and/or epigenetic modifications (eg, promoter hypermethylation) appear to be associated with a significant growth advantage, as opposed to normal skin cells. ${ }^{5}$ Furthermore, many molecular changes have been reported in advanced stages of melanoma, as opposed to normal melanocytes. The most common mutations are as follows: i) protoncogene serine/threonine kinase $B$-Raf-activating mutations, ${ }^{6}$ ii) E-cadherin expression silencing, ${ }^{7}$ and iii) telomerase activity acquisition, ${ }^{8}$ followed by hundreds more, identified by comparative gene expression profiling of melanomas with various American Joint Committee on Cancer stages. ${ }^{1,9,10}$

A recent article by Bennet ${ }^{1}$ provided a detailed list of possible genes involved in melanoma spreading and development.

Along with all pathways and molecules studied in different cancers, including melanoma itself, the study of the insulin-like growth factor (IGF) network of ligands, cell surface receptors, and IGF-binding proteins (IGFBPs; eg, the IGF-1 system) have attracted considerable interest because these pathways play important roles at multiple levels, from cellular and organ to organism. ${ }^{11-13}$ The IGF system mediates growth, differentiation, and developmental processes; it is involved in a variety of metabolic activities. ${ }^{13}$ Deregulation of IGF system expression and action is linked to several pathological features, ranging from growth deficits to cancer development. Tar-

Supported by the Italian Health Ministry (code ONC_ORD3207) and Programma strategico 3: Diagnostica ad elevata complessità e tecnologie per il monitoraggio di pazienti con patologie croniche-PROGETTO 4_ISS.

Accepted for publication August 10, 2010.

CME Disclosure: The author did not disclose any relevant financial relationships.

Address reprint requests to Ettore Capoluongo, M.Sc., Ph.D., Laboratory of Clinical Molecular Diagnostics, Department of Biochemistry and Clinical Biochemistry, Catholic University, Rome, Largo A. Gemelli 8, 00168, Rome, Italy. E-mail: ecapoluongo@rm.unicatt.it. 
Table 1. The IGF System Complex*

\begin{tabular}{clll}
\hline IGF ligands & \multicolumn{1}{c}{ IGF receptors } & IGF-binding proteins & Main effectors \\
\hline Insulin & Insulin receptor & IGFBP1-IGFBP6 & IRS-1 \\
IGF-1 & IGF-1 receptors A and B & IGFBP-related proteins & JCV-T \\
IGF-2 & IGF-2/mannose-6-phosphate receptor & IGFBP proteases & MAPKs \\
& $\begin{array}{l}\text { Insulin receptor-related receptor } \\
\text { Insulin/IGF-1 hybrid receptor }\end{array}$ & & PI3K/Akt \\
ALS & & &
\end{tabular}

IGF, insulin-like growth factor; IGFBP, IGF-binding protein; IRS, insulin receptor substrate; JCV-T, human polyomavirus JCV protein T; MAPK, mitogen-activated protein kinase; PI3K, phosphatidylinositol 3-kinase; Akt, antiapoptotic protein family; ALS, acid-labile subunit.

${ }^{*}$ The IGF-1 binds to IGFBP-3 in a 1:1 molar ratio. Other IGFBPs are inhibitory. For example, both IGFBP-2 and IGFBP-5 have a greater affinity for IGF-1 than the receptor. Therefore, increases in serum levels of these two IGFBPs result in a decrease in IGF-1 activity and vice versa. The ALS acts in the IGFs by binding circulating IGF-1 in a ternary complex together with binding protein IGFBP-3: ALS may influence skin carcinogenesis by modulating IGF-1 levels or its bioavailability. In addition, high circulating ALS levels reduce the concentration of free IGF-1 in circulation.

geting of the IGF axis emerged in recent years as a promising therapeutic approach for conditions in which the IGF system is involved. Specific IGF-1 receptor (IGF$1 \mathrm{R})$ targeting, in particular, produced the best experimental and clinical results, generating significant optimism in the field. ${ }^{14}$

Regarding what concerns melanoma and the IGF-1 system, literature data are often contrasting, mainly because of the following factors: i) cell line studied, ii) patient characteristics, iii) methods used for IGF-I assaying, iv) molecular profile analysis methods, and $v$ ) experimental model development. On the other hand, several recent articles emphasize the potential role played by IGF in melanoma development, ${ }^{15}$ in view of the fact that inhibitors of the IGF-1R are extensively studied for their ability to enhance the killing of a variety of malignant cells. ${ }^{16}$ Because of their pleiotropic properties, I believe that IGFs are capable of interplay with other molecules; this would be particularly true at the local level, where they could be produced by both cancer and metastatic cells. There are no exclusive sources of IGF-1, although macrophages and endothelial cells or cancer tissues $^{17}$ are considered among the main ones.

The present review discusses the meaning of the association between the IGF-1 system and sporadic malignant melanoma risk development. In addition, several specific malignancies in which the IGF system is involved are reviewed herein

\section{IGF System: Ligands, Receptors, and BPS}

As reported in Table 1, the main IGF ligands are IGF-1, IGF-2, insulin, and several nonclassic ligands with controversial biological roles. ${ }^{15-19}$ Insulin-like growth factor-1 is a cellular progression factor required by the cell to advance through the various phases of the cell cycle. ${ }^{18}$ Serum or plasma circulating IGF-1 levels are mainly dependent on production by the liver, which is tightly controlled by growth hormone. ${ }^{20}$ At the organ level, IGFs display paracrine and autocrine pathways, ${ }^{21}$ often interacting with vitamin $D,{ }^{22}$ inflammatory molecules, or locally produced factors (eg, suppressor of cytokine signaling, transforming growth factor- $\beta$, and steroid hormones; Figure 1). ${ }^{21-23}$ Insulin-like growth factors act through their receptors, which include the insulin receptor (IR), IGF-1R, IGF-2R, and several atypical receptors (eg, the IR-related receptor and the IRIGF-1R hybrid receptor $^{24}$ ), inducing mitogenic, antiapop- totic, and transforming activities. ${ }^{24}$ In particular, IGF-1R is a cell surface heterotetrameric tyrosine kinase receptor coupled to numerous intracellular second messenger pathways, including Raf/Ras-mitogen-activated protein kinase and phosphatidylinositol-3 kinase signaling cascades; for these reasons, IGF-1R is crucial for cell survival, whereas IGF-2 appears to have a tumor suppressor role because mutated or deleted forms have been reported in several cancers. ${ }^{25}$ In contrast, some reports did not confirm a role for IGF-2 in intracellular signaling, its bioactivity being mediated via a particular isoform of the IGF-1R (ie, IGF-1R-A) derived from an alternative splicing of the $I R$ gene. ${ }^{26}$

\section{IGF System and Cancer}

Insulin-like growth factor-1 is a multifunctional peptide that shares high structural homology with proinsulin. Along with the liver, other tissues are capable of producing this mediator on the basis of its local concentration. ${ }^{27}$ As opposed to IGF-2, which is considered a more active form during prenatal life, ${ }^{27}$ several IGFBPs are involved in the regulation or bioavailability of IGFs, the most abundant of which is IGFBP-3. ${ }^{28-30}$ This molecule regulates IGF-1 signaling by acting as a competitive inhibitor for IGF-1 by protecting it from accelerated degradation in circulation and facilitating its transport to target organs. ${ }^{29}$ Insulin-like growth factorBP-3 is also believed to have an IGF-independent inhibitory effect on cell growth that is mediated through a specific cell membrane receptor. ${ }^{30}$ In addition, in specific contexts, overexpression of IGFBPs (ie, IGFBP-2 and IGFBP-5) is associated with increased, rather than decreased, IGF action; adverse effects on cancer prognosis; and loss of the phosphatase and tensin homolog function. ${ }^{31,32}$ The mechanisms regarding the involvement of IGFBPs and IGF axis remain uncovered, although some hypotheses were reported by Pollak ${ }^{31}$ in his recently published review. On the other hand, some early (although not confirmed) reports described that higher circulating levels of IGF$1^{17}$ were associated with increased risk of prostate cancer, whereas higher IGFBP-3 serum levels were related to reduced cancer risk, suggesting a possible influence of IGFBP-3 in reducing IGF-1 bioactivity, in keeping with laboratory studies. ${ }^{31,32}$

Furthermore, growing evidence suggests that IGF-1 is involved in the pathogenesis of various types of human neoplasias, including breast, ${ }^{33}$ prostate, ${ }^{34,35}$ colon, ${ }^{36-38}$ 


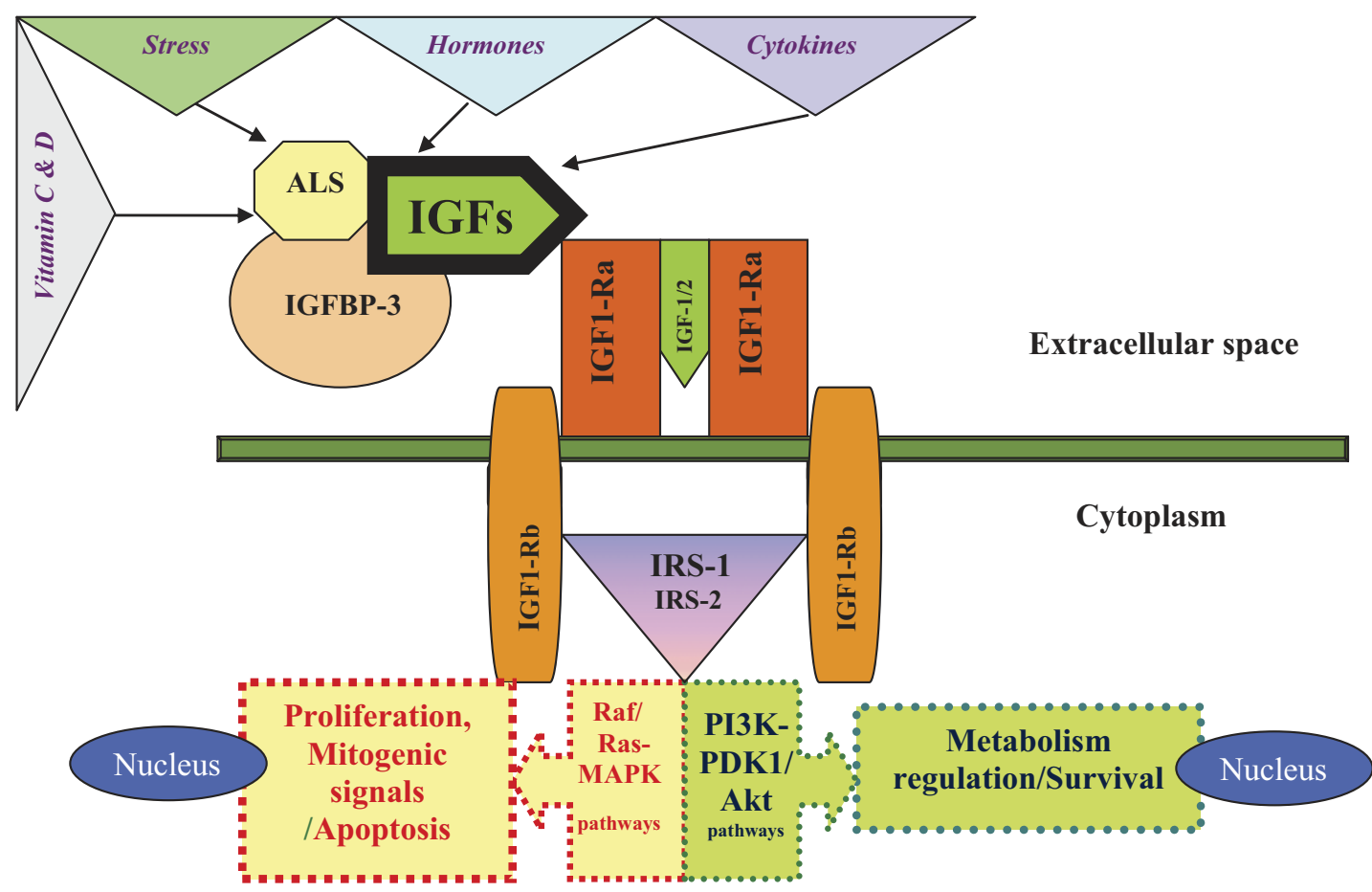

Figure 1. The biological actions of IGF-1 are mediated by IGF-1R and modulated by IGFBPs. Insulin-like growth factors 1 and 2 bind the extracellular domain of IGF-1R and induce the autophosphorylation of the tyrosine kinase (TK) receptor domain. The major IGFBP circulating in the serum is IGFBP-3; it circulates as a ternary complex formed by the BP-3 itself, the IGFs, and an acid-labile subunit. This complex protects IGFs from proteolysis, prolonging their half-lives in the bloodstream. The affinity of the IGFBPs for IGFs is generally higher than that of IGF-IR. The free IGF/BP-bound IGF ratio is crucial for the determination of the effectiveness of this growth factor. After IGF-1R activation, the insulin receptor substrates (IRSs) (eg, IRS-1) become phosphorylated, determining the activation of two main cascades (Ras/Raf-mitogen-activated protein kinase [MAPK] and phosphatidylinositol-3 kinase [PI3K]-PDK1[3'-phosphoinositide-dependent kinase-1]-antiapoptotic protein family/PKB [Protein Kinase B] pathways). In particular, one component of IGF-1 mitogenic signaling is mediated by TK through the association between the adapter protein Shc, growth factor receptor-binding (Grb) protein-2, and son of sevenless homolog (Sos)-1, which is capable of inducing both ras and MAPK cascades. The MAPK pathway modifies transcription activity at the nuclear level. Phosphorylation of IRS-1 and PI3K activation are also involved in IGF-1 signaling, similar to the action of insulin.

and lung ${ }^{39}$ cancers. The most appealing among these findings is that both IGF-1 and IGF-2 peptides are frequently expressed within neoplastic tissues, possibly influencing the previously mentioned cancers through autocrine, paracrine, or endocrine mechanisms. ${ }^{31}$ In addition, more recent large studies ${ }^{40,41}$ have suggested that particularly high circulating IGF-1 levels and/or low IGFBP-3 levels are associated with increased risk of several cancers, supporting a possible paracrine role of the IGF system in carcinogenesis. Furthermore, the negative correlation between IGFBP-3 levels and cancer risk is consistent with a protective role of IGFBP-3 (eg, high IGFBP-3 concentrations may lead to reduced free IGF-1 values). Insulin-like growth factor-1 circulating levels could also influence the cancer progression as follows: i) enhancing the proliferation of cell clones accumulating mutations, ${ }^{31}$ ii) modulating IGFBP serum or local concentrations, ${ }^{31}$ and iii) modulating IGF-1R activity or cell membrane density. ${ }^{31}$

Recently published data ${ }^{42,43}$ showed a strong influence of acid-labile subunit of the IGF-1 system (Figure 1), which is crucial in preventing the degradation of circulating IGF-1 and IGFBP-3 and in determining the IGF-1 availability to tissues. Data from a twin study ${ }^{44}$ indicated that $38 \%$ of the differences in IGF-1 and $60 \%$ of the differences in IGFBP-3 levels originate from genetic variations. Polymorphisms that are located in important regulatory regions, such as the promoter region or function- ally active domains, may affect the function of the IGF-1 protein. ${ }^{45,46}$ The measure of IGF serum levels is critical because it depends on the type of kit used and reflects a single or random point before or at diagnosis, when the interaction between IGFs and other cancer pathways has already occurred. The assay result in this particular patient could be considered an epiphenomenon. ${ }^{17}$

\section{Melanoma and Cell Proliferation Effects by IGF-1}

Clear effects exerted by IGF-1 on melanoma cells have already been reported. Proliferative effects on melanoma cells have been observed in vitro; in particular, cell migration (possibly mediated by interleukin-8 induction) was observed. ${ }^{47}$ These effects may be further increased by synergism with basic fibroblast growth factor and transforming growth factor- $\beta 1$, two mediators known to be induced by IGF-1. ${ }^{31,48}$ In addition, although melanoma cells were capable of expressing IGF-1 molecules in some studies, ${ }^{49}$ other reports ${ }^{15}$ did not confirm these findings.

Further genetic factors, such as IGF-1 microsatellites, may account for possible effects on melanoma risk or its aggressiveness. A strong association between melanoma severity (expressed as Breslow index) and the $/ G F-1(C A)_{19}$ repeat frequency was previously found. ${ }^{50}$ Concomitantly, serum IGF-1 concentrations were mainly reduced in indi- 
viduals with $/ G F-1(C A)_{19}$ microsatellite repeats compared with patients without $/ G F-1(C A)_{19}$ melanoma. Therefore, these results may have been obtained at diagnosis when melanoma was already present, suggesting that these concentrations could be a consequence of the cancer and its inflammatory component (generally decreased levels) ${ }^{50}$ rather than a predisposition marker of tumor development (increased levels). ${ }^{50}$ For the first time to my knowledge, serum IGF-1 levels were lower in patients with melanoma than in controls matched for age, sex, eye color, skin type, and body mass index. The same data were in agreement with the findings by other researchers in other cancer contexts. $^{31}$

\section{In Vitro and in Vivo Experimental Data: IGF-1 Molecular Signaling and Production in Melanoma Cells and Tissues}

Although Rodeck et $\mathrm{al}^{51}$ found that IGF-1 is not expressed in melanoma cells, Kanter-Lewensohn and coworkers ${ }^{49}$ showed that IGF-1R expression is correlated with melanoma progression, suggesting that paracrine-derived signals may determine IGF-1R activation during melanoma progression. In addition, Satyamoorthy et $\mathrm{al}^{47}$ found that fibroblast-derived IGF-1 promotes growth and survival of early-stage melanoma cells. Furthermore, Hilmi et $a^{52}$ stressed a role for IGF-1 in melanoma pathophysiological features because of IGF-1-mediated expression of the antiapoptotic proteins $\mathrm{Bcl}-2, \mathrm{Bcl}-\mathrm{X}(\mathrm{L})$, and survivin. This mechanism occurs through inhibition of TNF-related apoptosisinducing ligand-induced apoptosis, which is dependent on caspases-9 and $-3 .{ }^{52}$

Previous studies confirmed a role for IGF- 1 in the proliferation of early-stage melanoma cells but not metastatic melanomas, with little effect on melanoma spreading after the radial growth phase of the tumor. The hypothesized mechanism of melanoma disease progression is based on strong evasion of apoptosis. ${ }^{47}$ The specific cell type producing IGF-1 in the tumor microenvironment is still unknown. In addition, because stromal components were responsible for IGF-1 production in other cancer lesions, ${ }^{31}$ the same mechanism of synthesis could not be excluded for melanoma. In my opinion, it is clear that the in vitro condition is different from in vivo or ex vivo environmental situations; other factors may contribute to IGF-1 expressions both locally and systemically.

Finally, the IGFBP-3 promoter region was highly methylated in human melanoma samples compared with normal nevi. Indeed, Dar et $\mathrm{al}^{53}$ concluded that silencing of the IGFBP-3 promoter by methylation in melanoma cells inhibits its overexpression; in this way, apoptosis is suppressed, whereas cell survival and growth are stimulated.

\section{IGF-1R and Target Therapies for Cancer Treatment}

Insulin-like growth factor-1R plays a crucial role in normal development and in establishing and maintaining the malignant phenotype; its function has been critical for the pro- liferation and survival of cancer cells in several experimental settings. ${ }^{41}$ The effect on survival is mediated by multiple signaling intermediates, especially the phosphatidylinositol-3 kinase-antiapoptotic protein family pathway and the Ras/Raf-mitogen-activated protein kinase pathway. ${ }^{54}$

Moreover, because IGF-1R is overexpressed in malignant cutaneous melanoma but not in benign nevi, it is an attractive target for melanoma treatment. ${ }^{55}$

Inhibitors of IGF-1R have been widely studied for their ability to enhance the killing of some types of malignant cells and metastatic melanoma cells ${ }^{56}$; however, whether IGF-1 signaling differentially protects the host and cancer cells against chemotherapy has yet to be established. In fact, a recently published article showed that healthy cells and mice could be protected against chemotherapy-dependent damage by reducing circulating IGF-1 levels via a mechanism that involves down-regulation of proto-oncogene signals. ${ }^{56}$ Moreover, antisense oligonucleotides against IGF-1R mRNA were associated with reduced IGF-1R levels along with inhibition of IGF signaling pathways in several cancer types, including breast, prostate, lung, central nervous system, and bladder neoplasias. ${ }^{31}$

However, the identification of activating Ras/Raf mutations raises doubts about the efficacy of targeting IGF-1R because of its upstream location in the signaling cascade in human melanoma. Nevertheless, recent studies showed that this effect is independent of $B-R A F$ mutation status, suggesting that IGF-1R targeting may be an effective therapeutic approach for the treatment of melanoma and other tumors carrying activating mutations in the Ras/Raf-mitogen-activated protein kinase signaling pathway. ${ }^{57}$ The same was true when antiapoptotic protein family and extracellular signal-regulated kinase signaling was analyzed. ${ }^{57}$

Last, in the human melanoma cell line SK-MEL-2, IGF-1R expression was regulated by cyclooxygenase-2 expression, vitamin C, and IGF-2 via a feedback loop for amplification of IGF-1R expression by IGF-2. In particular, vitamin C down-regulation of IGF-1R in the human melanoma cell line SK-MEL-2 determines the inhibition of cell proliferation. Furthermore, vitamin C suppresses SK-MEL-2 proliferation through the inhibition of cyclooxygenase-2 expression and the modulation of IGF-2 production. ${ }^{58}$

\section{IGF-1 System and Uveal Melanoma}

An increasing amount of experimental data has been published concerning the strong correlation between the IGF system and uveal melanoma. In particular, the following interesting results were published: i) along with EGF, IGF-1 was involved in the development and progression of uveal melanoma; ${ }^{59}$ ii) IGF-1R appears to play a central role in that it is crucial for growth and survival and for invasion and metastasis of uveal melanoma cells $^{60}$; iii) by multivariate statistical analysis, Economou et al ${ }^{60}$ found that $34 \%$ of patients with low tumor IGF-1R expression died of metastatic disease, as opposed to $57 \%$ in the group with high IGF-1R expression; and iv) IGF-1R expression in uveal melanoma lesions may represent an important prognostic factor. ${ }^{60}$ Based on these findings, these researchers ${ }^{61}$ also suggested that target- 
ing this receptor may represent a strategy to treat this incurable disease and a strategy to prevent development of metastases in patients with primary disease.

\section{Conclusions and Perspectives}

Insulin-like growth factor and its family members have been extensively studied in some cancer types. The main results obtained by different groups on different types of neoplasias (eg, cutaneous, metastatic, and uveal melanomas) confirmed IGF's potential and often crucial role in tumor transformation, maintenance of malignant phenotype, promotion of cell growth, and prevention of apoptosis. In view of this, IGF-1R represents an attractive therapeutic target because its negative regulation would determine selective apoptosis and growth inhibition of tumor cells.

Although the previously mentioned mechanisms have been deeply analyzed by some researchers, the following questions remain unanswered: i) Are the molecular mechanisms played by IGF-1 on the induction of some molecules (eg, Bcl-2 and survivin) directly or indirectly exerted? ii) Are other pivotal molecules involved in the availability of IGFs at the tumor level? iii) Do the measurements of the IGF system molecules depict a peculiar instance of tumor status or do they represent a general pathophysiological mechanism of tumor progression? iv) Does the inhibition of IGF-1R synergize with traditional chemotherapeutic agents toward disease regression? and $v$ ) Are the in vitro conditions always superimposable to the in vivo conditions? These questions are complicated by the complexity of the IGF pathway. In fact, genetic and biochemical data regarding IGFs are often limited by heterogeneity among studied patients and experimental methods used.

Nevertheless, the central issue in this field is unraveling the mechanisms involved in the modulation of IGF-1R by its soluble IGF molecules in the context of an even more complex scheme, both at the tumor level and at systemic levels. A critical topic is represented by IGF-1R target therapy, as demonstrated by the increased articles published in the past 3 years. Although targeting therapy proved efficient in vitro, some generalized toxic adverse effects were reported despite the high targeting/receptor specificity of anti-IGF-1R targeting agents. This explains the broad range of IGF system targeting molecules and strategies still being investigated for the development of more efficient therapies, especially for melanoma. ${ }^{62}$ I believe that a better understanding of the complex machinery involved in the regulation of the IGF system in melanomas is required to provide new effective treatment strategies for those conditions in which the IGF system is directly involved.

\section{References}

1. Bennett DC: How to make a melanoma: what do we know of the primary clonal events? Pigment Cell Melanoma Res 2008, 21:27-38

2. Beddingfield FC 3rd: The melanoma epidemic: res ipsa loquitur. Oncologist 2003, 8:459-465
3. Rigel DS, Carucci JA: Malignant melanoma: prevention, early detection, and treatment in the 21st century. CA Cancer J Clin 2000 50:215-236

4. Gallagher RP, Spinelli JJ, Lee TK: Tanning beds, sunlamps, and risk of cutaneous malignant melanoma. Cancer Epidemiol Biomarkers Prev 2005, 14:562-566

5. Meyle KD, Guldberg P: Genetic risk factors for melanoma. Hum Genet 2009, 126:499-510

6. Dong J, Phelps RG, Qiao R, Yao S, Benard O, Ronai Z, Aaronson SA: BRAF oncogenic mutations correlate with progression rather than initiation of human melanoma. Cancer Res 2003, 15:3883-3885

7. Kuphal S, Bosserhoff AK: Influence of the cytoplasmic domain of $\mathrm{E}$-cadherin on endogenous $\mathrm{N}$-cadherin expression in malignant melanoma. Oncogene 2006, 25:248-259

8. Gray-Schopfer VC, Cheong SC, Chong H, Chow J, Moss T, AbdelMalek ZA, Marais R, Wynford-Thomas D, Bennett DC: Cellular senescence in naevi and immortalisation in melanoma: a role for $\mathrm{p} 16$ ? $\mathrm{Br} J$ Cancer 2006, 95:496-505

9. Ha C, Nosrati M, Sudilovsky D, Crothers J, Khodabakhsh D, Pulliam BL, Federman S, Miller JR 3rd, Allen RE, Singer MI, Leong SP, Ljung BM, Sagebiel RW, Kashani-Sabet M: The gene expression signatures of melanoma progression. Proc Natl Acad Sci U S A 2005, 102:60926097

10. Winnepenninckx V, Lazar V, Michiels S, Dessen P, Stas M, Alonso SR Avril MF, Ortiz Romero PL, Robert T, Balacescu O, Eggermont AM, Lenoir G, Sarasin A, Tursz T, van den Oord JJ, Spatz A, Melanoma Group of the European Organization for Research and Treatment of Cancer: Gene expression profiling of primary cutaneous melanoma and clinical outcome. J Natl Cancer Inst 2006, 98:472-482

11. Capoluongo E, Ameglio F, Zuppi C: Insulin-like growth factor-I and complications of prematurity: a focus on bronchopulmonary dysplasia. Clin Chem Lab Med 2008, 46:1061-1066

12. Metalli D, Lovat F, Tripodi F, Genua M, Xu SQ, Spinelli M, Alberghina L, Vanoni M, Baffa R, Gomella LG, lozzo RV, Morrione A: The insulinlike growth factor receptor I promotes motility and invasion of bladder cancer cells through Akt- and mitogen-activated protein kinase-dependent activation of paxillin. Am J Pathol 2010, 176:2997-3006

13. Larson Z: Insulin-like growth factor 1 (IGF-1): a growth hormone. Mol Pathol 2001, 54:311-316

14. Bruchim I, Attias Z, Werner H: Targeting the IGF1 axis in cancer proliferation. Expert Opin Ther Targets 2009, 13:1179-1192

15. Lee JT, Brafford P, Herlyn M: Unraveling the mysteries of IGF-1 signaling in melanoma. J Invest Dermatol 2008, 128:1358-1360

16. Lee C, Safdie FM, Raffaghello L, Wei M, Madia F, Parrella E, Hwang D, Cohen P, Bianchi G, Longo VD: Reduced levels of IGF-I mediate differential protection of normal and cancer cells in response to fasting and improve chemotherapeutic index. Cancer Res 2010, 70: 1564-1572

17. Schumacher FR, Cheng I, Freedman ML, Mucci L, Allen NE, Pollak MN, Hayes RB, Stram DO, Canzian F, Henderson BE, Hunter DJ, Virtamo J, Manjer J, Gaziano JM, Kolonel LN, Tjønneland A, Albanes D, Calle EE, Giovannucci E, Crawford ED, Haiman CA, Kraft P, Willet WC, Thun MJ, Le Marchand L, Kaaks R, Feigelson HS, Bueno-deMesquita HB, Palli D, Riboli E, Lund E, Amiano P, Andriole G, Dunning AM, Trichopoulos D, Stampfer MJ, Key TJ, Ma J: A comprehensive analysis of common IGF1, IGFBP1 and IGFBP3 genetic variation with prospective IGF-I and IGFBP-3 blood levels and prostate cancer risk among Caucasians. Hum Mol Genet 2010, 19:3089-3101

18. Werner H, Karnieli E, Rauscher FJ, LeRoith D: Wild-type and mutant p53 differentially regulate transcription of the insulin-like growth factor I receptor gene. Proc Natl Acad Sci U S A 1996, 93:8318-8323

19. Arcaro A, Doepfner KT, Boller D, Guerreiro AS, Shalaby T, Jackson SP, Schoenwaelder SM, Delattre O, Grotzer MA, Fischer B: Novel role for insulin as an autocrine growth factor for malignant brain tumour cells. Biochem J 2007, 406:57-66

20. Dupont J, LeRoith D: Insulin and insulin-like growth factor I receptors: similarities and differences in signal transduction. Horm Res 2001 55:22-26

21. Capoluongo E, Pitocco D, Lulli P, Minucci A, Santonocito C, Manto A, Di Stasio E, Zaccardi F, Zuppi C, Ghirlanda G, Ameglio F: Inverse correlation between serum free IGF-1 and IGFBP-3 levels and blood pressure in patients affected with type 1 diabetes. Cytokine 2006 34:303-311 
22. Capoluongo E, Zuppi C, Ameglio F: IGF-1 system, vitamin D and blood pressure relationships. Cytokine 2007, 37:183-184

23. Lelbach A, Muzes G, Feher J: The insulin-like growth factor system: IGFs, IGF-binding proteins and IGFBP-proteases. Acta Physiol Hung 2005, 95:97-107

24. Baserga R, Peruzzi F, Reiss K: The IGF-1 receptor in cancer biology. Int J Cancer 2003, 107:873-877

25. Leboulleux S, Gaston V, Boulle N, Le Bouc Y, Gicquel C: Loss of heterozygosity at the mannose 6-phosphate/insulin-like growth factor 2 receptor locus: a frequent but late event in adrenocortical tumorigenesis. Eur J Endocrinol 2001, 144:163-168

26. Frasca F, Pandini G, Scalia P, Sciacca L, Mineo R, Costantino A, Goldfine ID, Belfiore A, Vigneri R: Insulin receptor isoform A, a newly recognized, high-affinity insulin-like growth factor II receptor in fetal and cancer cells. Mol Cell Biol 1999, 19:3278-3288

27. Rosen CJ: Serum insulin-like growth factors and insulin-like growth factor-binding proteins: clinical implications. Clin Chem 1999, 45: 1384-1390

28. Jones JI, Clemmons DR: Insulin-like growth factors and their binding proteins: biological actions. Endocr Rev 1995, 16:3-34

29. Collett-Solberg PF, Cohen P: The role of the insulin-like growth factor binding proteins and the IGFBP proteases in modulating IGF action. Endocrinol Metab Clin North Am 1996, 25:591-614

30. Firth SM, Baxter RC: Cellular actions of the insulin-like growth factor binding proteins. Endocr Rev 2002, 23:824-854

31. Pollak M: Insulin and insulin-like growth factor signalling in neoplasia. Nature Rev Cancer 2008, 8:915-928

32. Bruning PF, Van Doorn J, Bonfrèr JM, Van Noord PA, Korse CM, Linders TC, Hart AA: Insulin like growth-factor-binding protein 3 is decreased in early-stage operable pre-menopausal breast cancer. Int J Cancer 1995, 62:266-270

33. Hankinson SE, Willett WC, Colditz GA, Hunter DJ, Michaud DS, Deroo B, Rosner B, Speizer FE, Pollak M: Circulating concentrations of insulin-like growth factor-l and risk of breast cancer. Lancet 1998, 351:1393-1396

34. Chan JM, Stampfer MJ, Giovannucci E, Gann PH, Ma J, Wilkinson P. Hennekens $\mathrm{CH}$, Pollak M: Plasma insulin-like growth factor-I and prostate cancer risk: a prospective study. Science 1998, 279:563566

35. Wolk A, Mantzoros CS, Andersson SO, Bergström R, Signorello LB Lagiou P, Adami HO, Trichopoulos D: Insulin like growth factor 1 and prostate cancer risk: a population-based, case-control study. J Nat Cancer Inst 1998, 90:911-915

36. Manousos O, Souglakos J, Bosetti C, Tzonou A, Chatzidakis V, Trichopoulos D, Adami HO, Mantzoros C: IGF-1 and IGF-1I in relation to colorectal cancer. Int J Cancer 1999, 83:15-17

37. Ma J, Pollak MN, Giovannucci E, Chan JM, Tao Y, Hennekens CH, Stampfer MJ: Prospective study of colorectal cancer risk in men and plasma levels of insulin-like growth factor (IGF)-I and IGF-binding protein-3. J Natl Cancer Inst 1999, 91:620-625

38. Giovannucci E, Pollak MN, Platz EA, Willett WC, Stampfer MJ, Majeed N, Colditz GA, Speizer FE, Hankinson SE: A prospective study of plasma insulin-like growth factor-1 and binding protein-3 and risk of colorectal cancer in women. Cancer Epidemiol Biomarkers Prev 2000, 9:345-349

39. Yu H, Spitz MR, Mistry J: Plasma levels of insulin-like growth factor-I and lung cancer risk: a case-control analysis. J Natl Cancer Inst 1999, 91:151-156

40. Allen NE, Roddam AW, Allen DS, Fentiman IS, Dos Santos Silva I, Peto J, Holly JM, Key TJ: A prospective study of serum insulin-like growth factor-I (IGF-I): IGF-II, IGF binding protein-3 and breast cancer risk. Br J Cancer 2005, 92:1283-1287

41. Werner $\mathrm{H}$, Bruchim I: The insulin-like growth factor-I receptor as an oncogene. Arch Physiol Biochem 2009, 115:58-71

42. Silha JV, Gui Y, Modric T, Suwanichkul A, Durham SK, Powell DR, Murphy LJ: Overexpression of the acid-labile subunit of the IGF ternary complex in transgenic mice. Endocrinology 2001, 142:4305-4313

43. Mucci LA, Stark JR, Pollak MN, Li H, Kurth T, Stampfer MJ, Ma J: Plasma levels of acid-labile subunit, free insulin-like growth factor-I, and prostate cancer risk: a prospective study. Cancer Epidemiol Biomarkers Prev 2010, 19:484-491

44. Harrela M, Koistinen H, Kaprio J, Lehtovirta M, Tuomilehto J, Eriksson J, Toivanen L, Koskenvuo M, Leinonen P, Koistinen R, Seppälä M:
Genetic and environmental components of interindividual variation in circulating levels of IGF-I: IGF-II, IGFBP-1, and IGFBP-3. J Clin Invest 1996, 98:2612-2615

45. Deal C, Ma J, Wilkin F, Paquette J, Rozen F, Ge B, Hudson T, Stampfer M, Pollak M: In insulin-like growth factor-binding protein-3 correlation with serum levels and interaction with known regulators. J Clin Endocrinol Metab 2001, 86:1274-1280

46. Schernhammer ES, Hankinson SE, Hunter DJ, Blouin MJ, Pollak MN: Polymorphic variation at the -202 locus in IGFBP3: influence on serum levels of insulin-like growth factors, interaction with plasma retinol and vitamin D and breast cancer risk. Int J Cancer 2003, 107:60-64

47. Satyamoorthy K, Li G, Vaidya B, Kalabis J, Herlyn M: Insulin-like growth factor-l-induced migration of melanoma cells is mediated by interleukin-8 induction. Cell Growth Differ 2002, 13:87-93

48. Lázár-Molnár E, Hegyesi H, Tóth S, Falus A: Autocrine and paracrine regulation by cytokines and growth factors in melanoma. Cytokine $2000,12: 547-554$

49. Kanter-Lewensohn L, Dricu A, Girnita L, Wejde J, Larsson O: Expression of insulin-like growth factor-1 receptor (IGF-1R) and p27Kip1 in melanocytic tumors: a potential regulatory role of IGF-1 pathway in distribution of p27Kip1 between different cyclins. Growth Factors 2000, 17:193-202

50. Santonocito C, Paradisi A, Capizzi R, Concolino P, Lavieri MM, Lanza Silveri S, De Luca D, Catricalà C, Di Carlo A, Zuppi C, Ameglio F, Capoluongo E: Insulin-like growth factor I (CA) repeats are associated with higher melanoma's Breslow index but not associated with the presence of the melanoma: a pilot study. Clin Chim Acta 2008, 390:104-149

51. Rodeck U, Melber K, Kath R, Menssen HD, Varello M, Atkinson B, Herlyn $\mathrm{M}$ : Constitutive expression of multiple growth factor genes by melanoma cells but not normal melanocytes. J Invest Dermatol 1991, 97:20-26

52. Hilmi C, Larribere L, Giuliano S, Bille K, Ortonne JP, Ballotti R, Bertolotto C: IGF1 promotes resistance to apoptosis in melanoma cells through an increased expression of BCL2, BCL-X $(L)$, and survivin. J Invest Dermatol 2008, 128:1499-1505

53. Dar AA, Maijid S, Nosrati M, de Semir D, Federman S, Kashani-Sabet M: Functional modulation of IGF-binding protein-3 expression in melanoma. J Invest Dermatol 2010, 130:2071-2079

54. O'Connor R: Regulation of IGF-I receptor signaling in tumor cells Horm Metab Res 2003, 35:771-777

55. Kanter-Lewensohn L, Dricu A, Girnita L, Wejde J, Larsson O: Expression of insulin-like growth factor-1 receptor (IGF-1R) and p27Kip1 in melanocytic tumors: a potential regulatory role of IGF-1 pathway in distribution of p27Kip1 between different cyclins. Growth Factors 2000, 17:193-202

56. Karasic TB, Hei TK, Ivanov VN: Disruption of IGF-1R signaling increases TRAIL-induced apoptosis: a new potential therapy for the treatment of melanoma. Exp Cell Res 2010, 316:1994-2007

57. Yeh AH, Bohula EA, Macaulay M: Human melanoma cells expressing V600E B-RAF are susceptible to IGF1R targeting by small interfering RNAs. Oncogene 2006, 25:6574-6581

58. Lee SK, Kang JS, Jung da J, Hur DY, Kim JE, Hahm E, Bae S, Kim HW, Kim D, Cho BJ, Cho D, Shin DH, Hwang YI, Lee WJ: Vitamin C suppresses proliferation of the human melanoma cell SK-MEL-2 through the inhibition of cyclooxygenase-2 (COX-2) expression and the modulation of insulin-like growth factor II (IGF-II) production. J Cell Physiol 2008, 216:180-188

59. Topcu-Yilmaz P, Kiratli $H$, Saglam A, Söylemezoglu F, Hascelik G Correlation of clinicopathological parameters with HGF, c-Met. EGFR, and IGF-1R expression in uveal melanoma. Melanoma Res 2010, 20:126-132

60. Economou MA, All-Ericsson C, Bykov V, Girnita L, Bartolazzi A, Larsson $O$, Seregard S: Receptors for the liver synthesized growth factors IGF-1 and HGF/SF in uveal melanoma: intercorrelation and prognostic implications. Acta Ophthalmol 2008, 4:20-25

61. Girnita A, All-Ericsson C, Economou MA, Aström K, Axelson M, Seregard S, Larsson O, Girnita L: The insulin-like growth factor-I receptor inhibitor picropodophyllin causes tumor regression and attenuates mechanisms involved in invasion of uveal melanoma cells. Clin Cancer Res 2006, 12:1383-1391

62. Rosenzweig SA, Atreya HS: Defining the pathway to insulin-like growth factor system targeting in cancer. Biochem Pharmacol 2010, 80:1115-1124 